\title{
Seropositivity of hepatitis b surface antigen in tertiary care centre: issues \& considerations
}

\author{
Kumar $\mathbf{S}^{1}$, Sayal $\mathbf{P}^{2}$, Budhani $\mathbf{D}^{3}$, Kumar $\mathbf{S}^{4}$ \\ ${ }^{1}$ Dr. Surinder Kumar, Head of Department, ${ }^{2}$ Dr. Pallavi Sayal, Demonstrator, ${ }^{3}$ Dr Diksha Budhani, Demonstrator, ${ }^{4}$ Dr. \\ Sumit Kumar, Associate Professor, all authors are affiliated with Department of Microbiology, BPS,GMC(W), Khanpur \\ Kalan, Sonepat, Haryana, India
}

Address for Correspondence: Dr. Pallavi Sayal, Demonstrator, BPS, GMC (W), Khanpur Kalan, Sonepat, Haryana. Email id: petalz03@gmail.com

\begin{abstract}
Background: Hepatitis B virus (HBV) infects more than 300 million people worldwide and is common cause of liver disease and liver cancer. HBV, a member of the Hepadnaviridae family, is a small DNA virus with unusual features similar to retroviruses. HBV replicates through an RNA intermediate and can integrate into the host genome. The unique features of the HBV replication cycle confer a distinct ability of the virus to persist in infected cells. Aims \& Objective: This study was designed to determine HBsAg Seropositivity among rural population attending inpatients and outpatients at tertiary care center with special consideration to childbearing age women. Material \& Method: This retrospective study was conducted in the Department of Microbiology for three months in a tertiary care center catering rural population. A total of 1463 patients attending outdoor and indoor, were screened for HBsAg by lateral flow based rapid immunochromatographic card test (ICT) manufactured by J Mitra \& Co Pvt Ltd. Results: Seropositivity of HBsAg was $41 / 1463(2.80 \%)$. Seropositivity was seen more in males $27 / 756(3.57 \%)$ as compared to females $14 / 707(1.98 \%)$. Age range 31-45 years was found to have highest prevalence rate with seropositivity of $15 / 279(5.38 \%)$. Among patients screened for HbsAg, we observed seropositivity of $2.37 \%$ (12/505) among women of childbearing age with age range 16 to 45 years. Conclusion: Findings in this study significantly contribute to the understanding of actual epidemiology of HBsAg in rural population especially women of childbearing age. Therefore, we should make efforts to prevent HBV infection by focusing on associated risk factors.
\end{abstract}

Key words: Hepatitis B, Childbearing age, Seropositivity, Rural population

\section{Background}

In 1965, Blumberg, while studying human serum lipoprotein allotypes observed in the serum of an Australian aborigine, a new antigen which gave clear defined line of precipitation with sera from two hemophiliacs who had received multiple blood transfusions. This was named as Australia antigen. By 1968 the 'Australia antigen' was found to be associated with serum hepatitis. It was subsequently shown to be the surface component of hepatitis B virus (HBV) and name was changed to hepatitis $B$ surface antigen (HBs $\mathrm{Ag}$ ) [1]. $\mathrm{HBV}$ is a partially double-stranded circular DNA virus belongs to class Hepadnaviridae. Viral

Manuscript received $19^{\text {th }}$ September 2016

Reviewed: $30^{\text {th }}$ September 2016

Author Corrected: $10^{\text {th }}$ October 2016

Accepted for Publication $19^{\text {th }}$ October 2016 particle is $42 \mathrm{~nm}$ in size and consists of an outer lipoprotein coat and surface antigen. HBsAg circulates in blood as viral particle-bound protein form or as free noninfectious protein presenting as $22-\mathrm{nm}$ spherical or tubular particles (free form predominates). Inner viral core contains hepatitis B core antigen ( $\mathrm{HBcAg}$ ), a double-stranded DNA molecule and hepatitis $\mathrm{B}$ e antigen (HBeAg), a soluble, non-particulate substance that is often present with core antigen.

Inner core also contains DNA dependent polymerase. Genome of HBV consists of the $\mathrm{S}$ gene, which codes for HBsAg; two pre-S region genes (pre-S1, pre-S2) that code for the hepatocyte receptor binding site; the $\mathrm{C}$ gene, which codes for $\mathrm{HBcAg}$ and $\mathrm{HBeAg}$; the $\mathrm{P}$ gene, 
which codes for a DNA polymerase; and an X gene that activates viral and cellular promoters. Although HBV is a DNA virus, it replicates in a way similar to retroviruses by making an intermediate RNA transcript [2].

Based on the prevalence of $\mathrm{HBsAg}$, different areas of the world are classified as high $(>8 \%)$, intermediate (2$7 \%$ ) or low $(<2 \%) \mathrm{HBV}$ endemicity. Since India has one-fifth of the world's population, it accounts for a large proportion of the worldwide HBV burden. India harbors $10-15 \%$ of entire pool, estimated around 40 million HBV carriers in world. About $15-25 \%$ of HBsAg carriers are likely to suffer from cirrhosis and liver cancer and may die prematurely [3].

Approximately one third of HBV infections occur via perinatal transmission and it is most important vertical transmission route of chronic hepatitis B infection. Women who have serological evidence of both HBsAg and $\mathrm{HBeAg}$ have significantly greater risk of transmission of HBV to their newborn as compared to women who have serological evidence of HBsAg only (85\% compared to $10 \%$ ) [4].

Thus, to understand and assess the magnitude and dynamics of transmission of a disease in a community and for its control and prevention, assessment and study of its prevalence is very important.

Epidemiological data on $\mathrm{HBV}$ infection is therefore important for strategies to tackle the spread of the disease. It is for these reasons this study was designed to determine $\mathrm{HBsAg}$ Seropositivity among rural population attending inpatients and outpatients at tertiary care center with special consideration to childbearing age women.

\section{Material \& Method}

This retrospective study was conducted in the Department of Microbiology for three months in a tertiary care center catering rural population. A total of 1463 patients attending outdoor and indoor, were screened for HBsAg by lateral flow based rapid immunochromatographic card test (ICT) manufactured by J Mitra \& Co Pvt Ltd.

Two $\mathrm{ml}$ venous blood of patients was collected and kept at room temperature to clot. Serum was separated by low centrifugation to get a clear supernatant and was subjected to immunochromatographic card test which is a onestep rapid quantitative two site sandwich immunoassay.

As the test sample flows through the membrane assembly of the device the colored monoclonal anti HBsAg colloid gold conjugate complexes with HBsAg in the sample. This complex moves further to the test region where it is immobilized by another monoclonal anti HBsAg antiserum coated on the membrane leading to the formation of pink purple colored band which confirms positive result. Only one pink band at the control region gives a negative test. Two pink bands both at the control and the test region gives a positive test.

\section{Results}

In present study, total of 1463 samples were tested for HBsAg .Out of 1463 samples, 1320 were from outdoor patients and 143 were from indoor patients. Overall seropositivity of HBsAg was 41/1463(2.80\%).

Demographic profile of patients enrolled in study were 756/1463(51.67\%) males and 707/1463(48.23\%) females. Seropositivity was seen more in males $27 / 756(3.57 \%$ ) as compared to females $14 / 707(1.98 \%)$. (Table 1)

\section{Table-1: Sample screened for HBsAg}

\begin{tabular}{|l|l|l|}
\hline Sample screened for HBsAg & Total Samples & Sample screened positive \\
\hline Males & 756 & $27(3.57 \%)$ \\
\hline Females & 707 & $14(1.98 \%)$ \\
\hline Total & $\mathbf{1 4 6 3}$ & $\mathbf{4 1}(\mathbf{2 . 8 0 \% )}$ \\
\hline
\end{tabular}

In our study age range 31-45 years was found to have highest prevalence rate with seropositivity of 15/279(5.38\%). Out of these, $7 / 279(2.50 \%)$ were females and $8 / 279(2.87 \%)$ were males. Seropositivity was low among elderly (>60 years) $5 / 1463(0.34 \%$ ) followed by children (age range <15 years) $3 / 1463(0.20 \%$ ) (Table 2). 
Table-2: Age \& Gender wise distribution of screened samples and HBsAg positive samples

\begin{tabular}{|l|l|l|l|l|}
\hline Age(In Years) & $\begin{array}{l}\text { Total male patients } \\
\text { screened }\end{array}$ & $\begin{array}{l}\text { Male patients } \\
\text { HbsAg positive }\end{array}$ & $\begin{array}{l}\text { Total Female } \\
\text { Patients screened }\end{array}$ & $\begin{array}{l}\text { Female patients } \\
\text { HbsAg Positive }\end{array}$ \\
\hline$<15$ years & 53 & 2 & 31 & 1 \\
\hline $16-30$ years & 206 & 6 & 353 & 4 \\
\hline $31-45$ years & 155 & 8 & 124 & 7 \\
\hline $46-60$ years & 190 & 7 & 69 & 1 \\
\hline$>60$ years & 152 & 4 & 43 & 1 \\
\hline
\end{tabular}

Among patients screened for HbsAg, we observed seropositivity of $2.37 \%$ (12/505) among women of childbearing age with age range 16 to 45 years (Figure 1 ).

Figure-1: Seropositivity among rural females of child bearing age

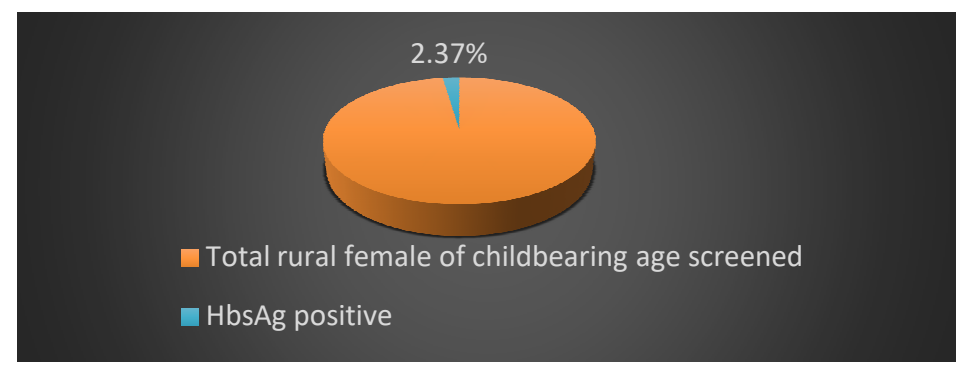

\section{Discussion}

We observed seropositivity of HBsAg was $2.80 \%$ in our tertiary care center. Overall rate of HBsAg positivity has been reported to range between $2 \%$ and $8 \%$ in most studies [5,6,7]. The widely quoted figure of a carrier rate in India is $4.7 \%$ with an estimated carrier population of 56.5 million [6]. Similar other studies conducted show variable results in reference to seropositivity of HBsAg (Table 3).

Table-3: Seroprevalence of HBsAg as documented by different authors

\begin{tabular}{|l|l|l|}
\hline Year & Author & Seroprevalence HBsAg \\
\hline 2015 & Kanodia et al [8] & $4.7 \%$ \\
\hline 2012 & Maratha Bhaskar Rao [9] & $7.6 \%$ \\
\hline 2011 & Patil et al [10] & $2.99 \%$ \\
\hline 2010 & Sood et al [11] & $0.87 \%$ \\
\hline 2007 & Choudhary et al [12] & $2.28 \%$ \\
\hline 2000 & Chandeasekaran et al [13] & $7.00 \%$ \\
\hline 2005 & Kurein et al [14] & $5.70 \%$ \\
\hline 1992 & William et al [15] & $7.40 \%$ \\
\hline
\end{tabular}

Out of total patients 756/1463(51.67\%) were males and 707/1463(48.23\%) were females. Seropositivity was seen more in males 27/756(3.57\%) as compared to females 14/707(1.98\%) (Table 1). Datta et al [16] observed HBsAg positivity rate of $35.3 \%$ in male and $19.3 \%$ in female, P. Jain et al [17] also reported positivity of HbsAg was more prevalent among males $62.54 \%$ in comparison to female $23.22 \%$. Kanodia et al [8] and Patil et al [10] also observed higher positivity among males compared to females. Quamer S et al [18] explained low seropositivity among females because probably they clear HBV more efficiently in comparison to males. Our study shows comparable findings of hepatitis B infection with the different authors from different parts of India.

In our study age range 31-45 years was found to have highest prevalence rate with seropositivity of 15/279(5.38\%). Out of these, $7 / 279(2.50 \%$ ) were females and $8 / 279(2.87 \%)$ were males. Similar results were found by Kanodia et al [8] and 
Atray D[19] with maximum seropositivity in age group 21-40 years i.e $40.39 \%$ and $53.35 \%$ respectively. This can be attributed to lack of proper knowledge and maximum exposure to the possible causes of the disease among this age group in rural areas.

Among patients screened for $\mathrm{HbsAg}$, we observed seropositivity of $2.37 \%$ (12/505) among women of childbearing age with age range 16 to 45 years (Figure 2). HBV infection is not just a risk for childbearing-age women; women with HBV infection can transmit the HBV to their newborns, children or other household members and sexual partners or spouses by vertical, horizontal, and sexual transmission. Vertical transmission contributes significantly to the persistence of plentiful chronic HBV infections [20]. Wang et al [21] reported seropositivity of $5.66 \%$ among childbearing-age women. Other authors [22,23,24] reported seropositivity of $9.51 \%, 3.77 \%$ and $4.53 \%$ which are higher as compared to our study.

\section{Conclusion}

Findings in this study significantly contribute to the understanding of actual epidemiology of $\mathrm{HBsAg}$ in rural population especially women of childbearing age. Therefore, we should make efforts to prevent HBV infection by focusing on associated risk factors. Targeted screening is not appropriate and universal screening would present cost constraints especially in resource-poor countries.

We suggest that a vaccination program funded by government should be implemented not only for infants and children, but also for women 15-45 years of age. In addition, premarital medical examination should be mandatory for women intending to get married. Women susceptible to HBV should have priority to get vaccinated.

Finally, health education is important and urgent, especially for childbearing-age women, especially agriculture workers, to increase their awareness of HBV infection and knowledge about transmission routes. It is imperative to reliably identify areas with higher endemicity than the rest of the country and to understand the risk factors associated with transmission of HBV. Further research is necessary to understand the causes and implications of this observation and to give future directions.

Funding: Nil, Conflict of interest: None initiated, Permission from IRB: Yes

\section{References}

1. Ananth Narayan, Paniker. Text Book of Microbiology, 8th Ed, Universities Press,India .2009; pp 538-9.

2. Gitlin N. Hepatitis B: diagnosis, prevention, and treatment. Clin Chem. 1997 Aug;43(8 Pt 2):1500-6.
3. Puri P.Tacking Hepatitis B disease burden in India.J Clin Exp Hepatol.2014 Dec;4(4):312-9. http://dx.doi.org/10.1016/j.jceh.2014.12.004.

4. Ho V, Ho W. Hepatitis B in pregnancy: Specific issues and considerations. J Antivir Anti retrovir. 2012;4(3):051-9. .doi:10.4172/jaa.1000046.

5. Abraham P. Viral hepatitis in India. Clin Lab Med. 2012 Jun;32(2):159-74. doi: 10.1016/j.cll.2012.03.003. Epub 2012 Apr 19.

6. Thyagarajan SP, Jayaram S, Mohanavalli B. Prevalence of HBV in general population of India. In: Sarin SK, Singal AK, eds. Hepatitis B in India: Problems and Prevention. New Delhi: CBS Publishers and Distributors; 1996:5-16.

7. Prevention of Hepatitis B in India - An Overview. New Delhi: World Health Organization South-East Asia Regional Office; 2002 Aug.

8. Veena Kanodia, Manju Yadav, Rameshwari Bittu, RK Maheshwari, S K Singh. Seroprevalence of Hepatitis B surface antigen in hospital based population of Jaipur, Rajasthan. Med Pulse - International Medical Journal.2015 Mar;2(3):123-5.

9. Dr. Maratha Bhaskar Rao. The prevalence of hepatitis B in India and its prevention with Ayurveda NAMAH, 2012, Jan;19(4):21.

10. SS Patil, SK Nikam, Sb Dama, RP Chondekar, RV Kirdar, LB Dama. Prevalence of hepatitis-B surface antigen (HBsAg) positivity in Solapur District, Maharashtra State, India. Bangladesh Journal of Medical Science. 2011 Apr;10(2):91-4.

11. Sood, S, Malvankar, S. Seroprevalence of Hepatitis B surface antigen, antibodies to the Hepatitis $\mathrm{C}$ virus, and human immunodeficiency virus in a hospital-based population in Jaipur, Rajasthan. Indian J Community Med.2010,Jan;35(1):165-9. doi: 10.4103/09700218.62588 . 
12. Choudhary AM, Khan SS, Majrooh A, Alvi AA.Seroprevalence of hepatitis-B and $C$ among the patients reporting in surgical OPD at Fauji Foundation Hospital, Rawalpindi: Review of 5 year literature. Pak J Med Sci.2007;23(4): 514-7.

13. Chandrasekaran S, Palaniappan N, Krishnan V, Mohan G, Chandrasekaran N. Relative prevalence of hepatitis $\mathrm{B}$ viral markers and hepatitis $\mathrm{C}$ virus antibodies (anti HCV) in Madurai, south India. Indian J Med Sci. 2000 Jul;54(7):270-3.

14. Kurien T, Thyagarajan SP, Jeyaseelan L, Peedicayil A, Rajendran P, Sivaram S, Hansdak SG, Renu G, Krishnamurthy P, Sudhakar K, Varghese JC; STD Study Group. Community prevalence of hepatitis B infection and modes of transmission in Tamil Nadu, India. Indian J Med Res. 2005 May;121(5):670-5.

15. Williams, TN, Wonke B, Donhue SMA. Study of Hepatitis B and C prevalence and liver function in multiply transfused thalassemic and their parents. Indian Pediatr.1992 Sept: 29(9):1119- 24.

16. Dutta S, Shivananda PG, Chatterjee A. Prevalence of hepatitis B surface antigen and antibody among hospital admitted patients in Manipal. Indian J Public Health. 1994 Jul-Sep;38(3):108-12.

17. Jain P, Prakash S, Gupta S, Singh KP, Shrivastava S, Singh DD, Singh J, Jain A. Prevalence of hepatitis A virus, hepatitis B virus, hepatitis C virus, hepatitis D virus and hepatitis $\mathrm{E}$ virus as causes of acute viral hepatitis in North India: a hospital based study. Indian J Med Microbiol. 2013 Jul-Sep;31(3):261-5. doi: 10.4103/0255-0857.115631.
18. Qamer S, Shahab T, Alam S, Malik A, Afzal K. Age-specific prevalence of hepatitis B surface antigen in pediatric population of Aligarh, North India. Indian $\mathbf{J}$ Pediatr. 2004 Nov;71(11):965-7.

19. Atray D, Sharma A, Atray M. Seroprevalence of Hepatitis B surface antigen in hospital based population in southern Rajasthan. India. Int J Curr Microbiol App Sci.2016;5(6):466-9.

http://dx.doi.org/10.20546/ijcmas.2016.506.053.

20. Yao GB. Importance of perinatal versus horizontal transmission of hepatitis $\mathrm{B}$ virus infection in China. Gut. 1996;38 Suppl 2:S39-42.

21. Wang M, Li H, Ji Y, Wang L, Ren T, Hou F et al. Seroprevalence of Hepatitis B surface antigen and hepatitis B e antigen among child bearing age women in Mianyang, China. J Infect Dev Ctries. 2015; 9(7):770-9. (doi:10.3855/jidc.6938).

22. Zhang Y, Fang WM, Fan LC, Gao XH, Guo Y, Huang WM et al. Hepatitis B surface antigen prevalence among 12393 rural women of childbearing age in Hainan Province, China: a cross-sectional study. Virol J.2013;10: 25.

23. Guo YH, Li J, Liu Q, Xu J, Feng XH, Ye Y et al. A serological survey of hepatitis B virus and risk factors among women of child-bearing age in Henan Province. Chin J Dis Control Prev. 2012;18:601-5.

24. Ji F, Zhang L, Yan BY, Li MS, Song LZ, Xu AQ.Analysis on Hepatitis B Virus Infection among Women at Childbearing Age in Shandong Province. Prev Med T Rib.2006;16: 781-3.

\section{How to cite this article?}

Kumar S, Sayal P, Budhani D, Kumar S. Seropositivity of hepatitis b surface antigen in tertiary care centre: issues \& considerations. Int J Med Res Rev 2016;4(10):1756-1760.doi:10.17511/ijmrr. 2016.i10.07. 